\title{
特集「不動産競売制度の現状及び制度改善に向けた考察」にあたって Study for the present conditions of the real estate auction system and the improvement of its system
}

\author{
富田＼cjkstart裕（弁護士，出版編集委員）
}

Yu TOMITA

不動産競売制度に関しては, 短期賃貸借制度の廃止や最低売却価額制度の廃止により大きく改 善したといわれる。

しかしながら，短期賃貸借制度の代わりにできた明渡猶予制度の占有者保護により落札価格が 下落する問題, 最低売却価額制度の代わりにできた売却基準価額制度が落札の妨げとなっている 問題, 不動産競売では売主の瑕疵担保責任がない問題, 建物の内覧制度が十分活用されない問題 等, 改善の余地はまだまだあると思われる。

また, アメリカにおける非司法競売の成功例にならった制度を導入することで，裁判所による 競売よりもより早く，より高い取引を実現できるとの提言もなされている。

このように, 不動産競売制度については, 短期賃貸借制度がなくなったから問題は終わったと いうものではなく，現段階でも未だ検討すべき課題は存在している。

そこで, 本特集では, 日本の不動産競売制度の現状の問題点を把握するとともに，今後の制度 改善に向けた多角的な検討をすることとした。

福井論説は, かつて存在した短期賃貸借保護制度, 最低売却価額制度が競売不動産の取引費用 を非常に高いものにしていたことを経済学の視点から詳細に分析し，これらの制度がなくなった ことで競売不動産の落札価額が上昇する等改善が認められたことを述べるとともに，アメリカの 民間競売制度を参考に日本でも民間競売制度を導入することを提案している。

井出論説は，2004年以前と2017年の不動産競売を比較すると，2017年には「占有者あり」の物 件を「法人」が高い上乗せ率（基準価額に対する売却価額の割合）で落札する傾向があることを 分析し, 現在の不動産競売は法人ビジネスにおける仕入れ市場の要素が強くなってきていると評 価している。

森岡論説は, 一般仲介物件と比較した不動産競売物件の価格下落効果について，2004年の短期 賃貸借制度，最低売却価額制度撤廃の影響で2001年時点の $44 \%$ の価格下落から 2006 年時点の $26 \%$ の価格下落となったが，その後，2010年時点では再び下落幅が広がり，35\%の下落幅となってい ることを示し，競売市場にはまだ改善の余地があることを述べている。

大岡論説は, 現行不動産競売制度のさらなる制度改正の方向として, デー夕掲載範囲の拡充, 内覧手続の改善, 入札時の下限価格の参考価格への変更, 所有権移転と同時の物件の引渡しの実 施, 瑕疪担保責任の導入, オークション方式の検討, 債務者の売却協力のインセンティブ措置と してのデポジット制度（融資金額の一定割合を債務者に拠出させ，売却に協力した場合に債務者 に支払う制度）等を提案している。

丸岡論説は, 明渡猶予制度を導入した後も明渡猶予制度が 6 か月間の猶予期間を設けていること から落札価額を 8 \%下落させていることをデータにより示し, 明渡猶予制度の廃止を提案している。

富田論説は, 不動産競売の取引費用低減のための制度改善として, 債務者が競売手続に協力し た場合に，債務者に対し，落札価額の 1 割を上限とした報奨金を交付する制度を提案している。 